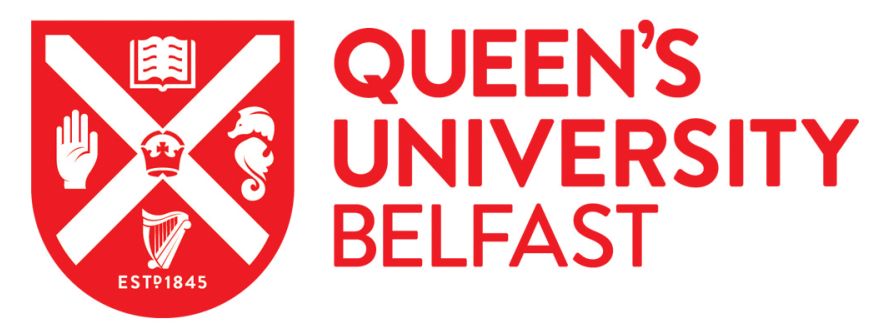

\title{
Transforming the Irish Presidency: Activist Presidents and Gender Politics, 1990-2011
}

Galligan, Y. (2012). Transforming the Irish Presidency: Activist Presidents and Gender Politics, 1990-2011. Irish Political Studies, 27(4), 596-614. https://doi.org/10.1080/07907184.2012.734451

Published in:

Irish Political Studies

Document Version:

Peer reviewed version

Queen's University Belfast - Research Portal:

Link to publication record in Queen's University Belfast Research Portal

Publisher rights

Copyright 2012 Political Studies Association of Ireland

This is an Accepted Manuscript of an article 20/11/2012, available online: http://www.tandfonline.com/0.1080/07907184.2012.734451.

\section{General rights}

Copyright for the publications made accessible via the Queen's University Belfast Research Portal is retained by the author(s) and / or other copyright owners and it is a condition of accessing these publications that users recognise and abide by the legal requirements associated with these rights.

Take down policy

The Research Portal is Queen's institutional repository that provides access to Queen's research output. Every effort has been made to ensure that content in the Research Portal does not infringe any person's rights, or applicable UK laws. If you discover content in the Research Portal that you believe breaches copyright or violates any law, please contact openaccess@qub.ac.uk. 


\section{7 / Transforming the Presidency: Activist Presidents and Gender Politics Yvonne Galligan}

\section{Introduction}

The outcome of the 1990 and 1997 presidential elections brought two women into Áras an Uachtaráin, heralding a discernable change of pace, tone, and focus in the office. The relatively staid backwater that was the received image of the Irish presidency became charged with a new political energy. This transformation rested on the personalities of Mary Robinson and Mary McAleese. However, personal disposition alone does not fully explain their development of a more activist presidency. Their respective political agendas motivated much of this new interpretation of the office. So too did their differing conceptions of the role of the President. While staying within constitutional boundaries, both women sought to add content to a political institution that in the public mind had become apolitical, even irrelevant. Their lasting achievement was to reconstruct the nature of the Presidency from being a sinecure for elder statesmen, to being a political institution that evoked public pride in its representative function.

This chapter traces the transformation of the Irish presidency between 1990 and 2011. It takes each president in turn, and, following discussion of personal background, it looks at the path to the presidency, vision of office and political role. It analyses their inaugural speeches to uncover the defining themes of each presidency, and discusses the extent to which each woman fulfilled this self-chosen agenda in subsequent years. The inaugural address marks a significant moment in a presidential term of office. It allows space for the newly-installed incumbent to reassure voters that they have made the right choice of President. It gives the new President the opportunity to acknowledge the democratic link between the people and the office, and it provides a formal public stage for the incoming President to indicate the nature of the relationship she hopes to foster with the people. It also allows the new officeholder to indicate priorities, and set the tone, for the next seven years of the presidency. In the third section, the discussion moves to evaluating the transformative extent of the Robinson and McAleese presidencies. It concludes by reflecting on the cultural symbolism of the office and the contributions of the two women to refashioning the presidency for modern times.

\section{Mary Robinson, 1990-97}

In this section, Mary Robinson's path from her early years to the presidency is discussed, followed by an analysis of her vision for the office and an overview of her presidential term. Born in Ballina, County Mayo on 21 May 1944, Mary Bourke (her pre-marriage surname) was 
the middle child and only girl in a family of five children. Coming from a prosperous professional family, the Bourke children were encouraged to achieve, and given every material and emotional support to do so. In 1963, on securing permission from Catholic authorities to attend Trinity College Dublin, Mary Bourke commenced her studies in legal science. ${ }^{1}$ She became auditor of Trinity's Law Society in 1967, and chose as the theme of her inaugural address the separation of church and state. In this speech she raised two of the issues that would later become important motifs in her political and legal career, divorce and contraception (O'Leary and Burke, 1998: 30-32). Graduating with first class honours in 1967, she commenced a fellowship at Harvard Law School. Mary Bourke immersed herself in this environment where the questioning of the relationship between law, politics, and society provoked passionate debate. She returned to Ireland with a first class Masters degree. A year later, in 1969, as an apprentice barrister and part-time law tutor at University College Dublin (UCD), she was elected to one of the three Trinity seats in the Seanad (Senate, upper house of parliament), and began a thirty-year career in Irish politics. In 1970, she married Nicholas Robinson whom she met during her student years.

Robinson's legal and political careers fused on human rights and law reform issues. She has attributed her abiding sense of justice and human rights to the influence of her father and grandfather, and the experience of growing up in a medical practice household (Horgan 1997:14; O'Leary and Burke 1998: 15-16). One of her first legislative acts was to introduce a private member's bill in the Seanad on reproductive rights in 1971 that sought to make contraception legally available. In 1976 she joined the Irish Labour Party and the following year ran for election to the Dáil (lower house) in the Dublin south city constituency of Rathmines. She failed to win a seat by 400 votes and resumed her Seanad career. Another Dáil election attempt, this time in the Dublin West constituency in 1981, was also unsuccessful. Robinson again resumed her Seanad career while maintaining an active legal practice. In 1985 she resigned from Labour in protest at the Anglo-Irish agreement which she described as 'fatally flawed', as it was based on intergovernmental structures negotiated between the Irish and British governments without the input of unionist political leaders (Horgan, 1997: 113-115). ${ }^{2}$ In 1989 Robinson took the decision to concentrate on her academic and legal career. Less than one year later, she was a candidate for the presidency.

\section{Emergence as President}

In 1990, President Hillery's second term was coming to a close. The name of Brian Lenihan, a popular Fianna Fáil minister and ally of Taoiseach (prime minister) and party leader Charles J. Haughey, began to circulate informally in late 1989 as the party's choice to succeed Hillery (Horgan, 1997: 125). At the same time, Labour's strong 1989 election result encouraged Labour leader Dick Spring to announce in early January that the party would 
contest the presidential election for the first time (Finlay, 1990: 12). Although Spring had no one person in mind at that time, Mary Robinson's name quickly came to the fore. After some negotiation, Robinson expressed a willingness to accept a nomination, but as an independent candidate. In April 1990, her candidacy was officially endorsed by Labour after the alternative possibility of Noel Browne, canvassed by the party's radical wing, disappeared (Horgan, 1997: 129-30; Finlay, 1990: 18-24). Robinson's candidacy quickly drew support from two other small left-leaning parties, the Green Party and the Workers' Party. She launched her campaign in May with a low-key tour of the country, visiting remote and island communities as well as small towns and urban areas, listening to their expectations of a president.

In June, Lenihan saw off a challenge from party colleague and former Minister for Education John Wilson to become the Fianna Fáil presidential candidate. Meanwhile, there were problems with Fine Gael's efforts to secure a nominee. Former leader Garret FitzGerald and former Tánaiste (deputy prime minister) Peter Barry refused invitations to put their names forward. Eventually, in September, the party nominated a former Northern Ireland politician, Austin Currie, who was then a Fine Gael TD in Dublin West. ${ }^{3}$ Fine Gael leader Alan Dukes, whose authority had already been undermined by the poor party showing at the 1989 election, lost further standing over the candidacy debacle (O'Sullivan, 1991: 87-90).

Robinson's early campaign start gave her time to meet people and groups across the country, engaging them in a discussion about the role of the President in modern Ireland. She integrated these views with her own vision for the office, and encapsulated the combined views in the campaign slogan 'a president with a purpose'. The other candidates, responding to her redefinition of the office, also promised an activist presidency: Lenihan as a 'people's president' offered to promote Ireland's heritage and culture at home and abroad; Currie imagined the President as a 'reconciling figure' (O'Sullivan, 1991: 90-91).

In addition to being the first candidate in the field to articulate a clear and modern vision for the office, Robinson also gained from the mistakes of her opponents during the campaign. Lenihan stumbled when he was forced to clarify, and then retract, a claim that he had sought to influence President Hillery not to dissolve the Dail in 1982. In brief, Lenihan had publicly denied that he had asked President Hillery to refuse a dissolution of parliament to the incumbent Taoiseach, Garret FitzGerald during a period of political crisis. However, his statements were challenged when a tape recording was made public on which Lenihan admitted to having made persistent phone calls to Áras an Uachtaráin, and claimed to have spoken with the President, for that purpose. Lenihan repeated his denial that the phone call took place, explaining that he had been under heavy medication at the time of the interview that had affected his recollection of events. The affair undermined Lenihan's credibility as a 
candidate. The controversy soured relations between the governing parties, Fianna Fáil and the Progressive Democrats (PDs), and ultimately leaked into parliamentary politics. The PDs insisted on Lenihan's resignation from cabinet as a condition for their support of Fianna Fáil in a no-confidence vote tabled by the opposition. Lenihan refused to resign and was removed from office by Haughey. Ironically, the Lenihan campaign gained renewed impetus after this episode and he began to claw back much of the support he had earlier lost to Robinson during the controversy (Finlay, 1990: 122-125, 127; O'Sullivan, 1991: 91-94)).

Robinson's own campaign came under pressure in the final days. Her commitment to social justice was cast as 'red' politics by Fianna Fáil. In a similar vein, Fianna Fáil cabinet minister Padraig Flynn on a radio current affairs programme launched a personalised attack on Robinson, accusing her of being an opportunistic socialist candidate with no empathy for the lives of ordinary people, while masquerading as a caring politician. In a blistering tirade, Flynn went on to criticise her 'new clothes and her new look and her new hairdo and she has the new interest in family, being a mother and all that kind of thing', adding 'None of us who knew Mary Robinson very well in previous incarnations ever heard her claiming to be a great wife and mother' (Finlay, 1990: 135). The sexist attack was immediately roundly countered by PD representative Michael McDowell, a panellist on the same radio programme. Although Flynn offered a profuse apology soon thereafter, his outburst spectacularly backfired on the Lenihan campaign and pushed voters towards Robinson. On the eve of the election, Lenihan and Robinson were evenly matched in public support - and it is likely that this incident contributed to consolidating Currie transfers to Robinson. Although Lenihan won $44 \%$ of the first preference vote while Robinson garnered 39\%, more than three-quarters of Currie's votes transferred to Robinson, handing her victory on the second count (O'Sullivan, 1991: 95-96).

\section{Vision of office}

Robinson's electoral victory was described at the time as 'mould-breaking': the first woman to hold the office, the first time the position was held by a politician from a party other than Fianna Fáil. Robinson's shaping of the presidential office as a purposeful one, which began during the election, continued during her tenure. Her campaign slogan was carefully crafted to the image of a president prepared to use the soft power of the office to validate individual and collective efforts to improve the quality of civic and democratic life in Ireland and further afield. Robinson knew that her election was a reflection of the changes taking place in Irish society and political culture. It was, as Stephen Lucas put it, a 'moment of consequence'4 and her inaugural address gave the new President an opportunity to define her vision of the state and nation in response to her mould-breaking election. Previous incumbents of the office, by and large, had been content to interpret their presidential role in a conventional manner - as 
defenders of the constitution (Ó Dálaigh, Hillery) and low-key supporters of volunteerism and social good works (Childers, Hillery). Robinson was at pains to stress her break with the received interpretation of the institution.

In her inaugural address (Robinson, 1990), the new President made extensive reference to aspects of 'new' and 'modern' Ireland and her desire to support empowering civic and social values and activities. For Robinson, this new sense of Irishness was inextricably bound to closer integration with Europe and underpinned by the liberal norms of 'respect for human rights, pluralism, tolerance and openness to new ideas', which were for her core political values.

Although her electoral victory was decisive, Robinson also acknowledged in her address that not all of her electors endorsed her political views. Thus, one of the purposes of her inaugural speech was to create a bond of friendship between her as President and the people, so as to consolidate the legitimacy of her presidency. She intended to create this connection through emphasising her office as a focus for local and community attention in all its forms, promising that 'As President I will seek to the best of my abilities to promote this growing sense of local participatory democracy'.

By recognising the diversity of political views among her electors, and binding all, including herself, to promoting 'a new Ireland, open, tolerant, inclusive' she went on during her presidency to be a 'witness' to these impulses. She carefully chose the events she supported, by her presence drawing attention to instances of civic action and multi-cultural engagement across the island. As Bresnihan (1999: 250-265) observed, Robinson set out to symbolise a politics based on 'strong democracy' and 'nurturing reason'.

\section{Political role}

Robinson explicitly spelled out her interpretation of the head of state's representative function in the inaugural address, and in the following years developed the office according to the values she articulated on taking office. Her active interpretation of this representative office led to conflict in the early years with Taoiseach Charles J. Haughey and officials in the Department of the Taoiseach who were accustomed to working with a more traditional, lowkey interpretation of the presidency. A defining moment in this relationship came with the visit of the Dalai Lama to Ireland in 1991, and Robinson's expressed intention to formally recognise him as representative of the Tibetan people. Haughey repeatedly sought to deter her from meeting the Dalai Lama, but finally backed down when Robinson stood her ground (O'Leary and Burke, 1998: 154-156). From that point onwards, Robinson grew in confidence and skill in using the symbolic power of her office to recognise, support and validate the 'new, pluralist Ireland' of her inaugural speech. 
One aspect of her presidential agenda to which she applied considerable thought and diplomacy was in building a relationship with Queen Elizabeth II as a symbol of the growing friendship between the two states. This began in April 1991 with the breaking of an unwritten convention - that Irish presidents do not visit Britain - and culminated in June 1996 with an official visit to Britain. In between came the symbolically important reconciliatory event on 27 May 1993 when the Irish President paid a personal visit to the Queen, the first meeting of an Irish president and a British monarch (Siggins, 1997: 164).

Robinson skilfully used her gender as a woman to political effect, recognising marginalised women and their efforts to create better lives for their communities across the island. It was the wedge that unblocked another barrier to the scope of the presidency, this time a visit to Northern Ireland. Until Robinson accepted an invitation from women's groups from both communities in Belfast in February 1992, Irish presidents had confined their cross-border visits to events of a religious nature in Armagh, seat of the Catholic Church in Ireland. This visit helped to pave the way for her controversial visit to west Belfast in June 1993, on the invitation of community representatives. This initiative was strenuously objected to by the British government, the Northern Ireland Office, and Northern unionists. The British government went so far as to hint that it might not be able to guarantee her personal safety while in the jurisdiction (Siggins, 1997: 166). The Irish government, too, was unhappy with the visit - independently of the British view - with concerns that Sinn Féin would hijack the event for propaganda purposes, and sought to deter Robinson. Dick Spring, then Minister for Foreign Affairs in the Fianna Fáil-Labour coalition government, was tasked with conveying this disquiet, along with conveying the negative view of the British government, to the planned visit. Increasing heat marked the exchanges between President and Government leaders on the matter. No official prohibition on the President's travel arrangements came, and although Spring remained opposed to it, the Taoiseach was more sanguine in his view. On 18 June 1993, three weeks on from the symbolic meeting with the Queen, President Robinson attended the Whiterock Road campus of the Belfast Institute of Further and Higher Education and shook hands with representatives from over 50 community and civic organisations (nationalist and unionist), local councillors, Joe Hendron of the SDLP and Gerry Adams, President of Sinn Féin. Photographers were excluded from the venue. This did not prevent an outbreak of condemnation for her actions from political leaders, Irish and British media commentators, Fine Gael, and the Northern Ireland Office (O'Leary and Burke, 1998: 208-218). The public, however, viewed the visit and the Adams handshake differently, with an Irish Independent poll showing $77 \%$ approval of the President's action (Fortnight, 320, Sept. 1993: 30). The public response indicated that there was general support in the Republic of Ireland for a peace process that included Sinn Féin. 
In her inaugural address, Robinson had sought to represent Ireland in the promotion of human rights on the international stage. As President, she sought to realise this promise through visiting famine-stricken Somalia. Irish aid agencies working in Somalia organised the visit, and Robinson's emotionally powerful response to her experiences brought the grim reality of poverty and hunger to world attention. She was to follow the Somalia visit with three visits to Rwanda, forming a view of the political and practical action required to address human rights and development needs in these countries. These visits, and her international advocacy for a rights-based development agenda, laid the foundations of her later career in the United Nations. While President, her actions in this area showed that Ireland, a small country, could make a significant contribution to international affairs in humanitarian terms. Although she was by then growing out of the presidential role and into a new international one, Robinson skilfully used the presidency to keep her inauguration promise.

By the time Mary Robinson announced she would not seek a second term as President, she enjoyed over 92\% support in opinion polls (Marsh, 1999: 217). She had accepted thousands of invitations to local official events, supported the work of the traveller community, women's groups, and social justice organisations. She had played a central part in normalising the political relationship between Ireland and Britain, and between north and south in Ireland. She had represented Ireland extensively abroad, including 10 state visits. She worked with three different prime ministers and two different administrations. In the course of her presidential term, Robinson tackled the constitutional limitations of the office by negotiating her role with successive Taoisigh (prime ministers), finding the spaces on which the constitution was silent and using these opportunities to represent aspects of Irish cultural and social values. Robinson had lived up to her vow to be a 'president with a purpose'.

\section{Mary McAleese, 1997-2011}

Mary McAleese emerged from a fraught electoral campaign to succeed Mary Robinson to the presidency. The contrast between the two women's backgrounds is striking. While their political views and ambitions for the office were also different, both shared an ambition to maximise the President's representative role. The following sections discuss these matters in more detail. Mary Leneghan was born in Belfast on 27 June 1951, the eldest of nine children. Her parents were small business owners in the mixed-community Ardoyne area of north Belfast. As the family enlarged, the Leneghans moved to a mainly Protestant part of Ardoyne, where the young Mary Leneghan was taunted occasionally on account of her religious background. Her father's keen interest in local history and her mother's family interest in republican politics shaped her Catholic nationalist identity. ${ }^{5}$ She also inherited a strong sense of social justice and commitment to peace from her parents (McGarry, 2008: $51-2)$. 
A high achieving student in the all-girls St Dominic's High School, in 1969 Leneghan went on to study law in Queen's University Belfast. Her time at Queen's coincided with the beginning of the communal conflict, from which the family was not immune. Over the course of the following years, her brother and sister were injured in separate sectarian attacks, Mary was caught in crossfire between the British Army and the IRA, and a car bomb destroyed her father's public house business on the Falls Road. A machine gun attack on the Leneghan home during the night of 7 December 1972 instigated a family move away from north Belfast and eventually to the more peaceful seaside town of Rostrevor, Co. Down.

During that troubled period, Mary Leneghan continued her legal studies, and graduated with honours in 1974. She briefly practiced at the Northern Ireland Bar and in 1975 was appointed Reid Professor of Criminal Law at Trinity College Dublin, ${ }^{6}$ succeeding Mary Robinson in the post. In 1976 she married Martin McAleese. In Dublin she became involved in some of the controversial social issues of the day, founding the campaign for homosexual law reform with David Norris, supporting the introduction of divorce, and championing moves to ban abortion in Ireland (McGarry, 2008: 78-83). Indeed, she advocated a strong and inclusive notion of marriage and family throughout her public life, supporting gay marriage independent of Catholic doctrine (McGarry, 2012).

In 1979 she joined the state broadcasting service, RTÉ, as a journalist, working on the flagship television current affairs programme, Today Tonight. Her nationalist roots and personal experience of the conflict became quickly at odds with the anti-nationalist viewpoint of the current affairs editor and producers. A defining moment came when the Today Tonight editor, Joe Mulholland, refused to cover the funeral of IRA hunger striker Bobby Sands on the grounds that it would constitute propaganda for the republican movement. McAleese argued that the hunger strikes were radicalising the nationalist community, with deep implications for Northern Ireland's politics, and that this event could not be ignored. She quit RTÉ after an unhappy three years, and resumed her Trinity position although in 1983 she returned to RTÉ as a freelance reporter and broadcaster, while continuing to lecture in law in Trinity. By all accounts a consummate presenter, McAleese became embroiled in a quarrel ostensibly over 'double jobbing' with the National Union of Journalists (NUJ). A union rule required members to earn at least two-thirds of their salary from journalism, and it was alleged that McAleese breached that rule. For her part, McAleese argued that the charge against her was politically motivated and stemmed from her appearance with the Catholic bishops at the New Ireland Forum. She challenged the NUJ to take a stance on all broadcasters with second careers, to no avail. On 31 March 1984 McAleese was suspended from the NUJ's Dublin Broadcasting Branch, though this did not prevent her from continuing her part-time broadcasting activities with RTÉ (McCarthy, 1999: 64-67; Mac Mánais, 2004: 203-206). 
Shortly before the spat with the NUJ, McAleese was invited to join the Catholic Church delegation to the New Ireland Forum in 1984. In this capacity she debated the merits of integrated education versus denominational schooling with then Senator Mary Robinson (O'Leary and Burke, 1998: 91-92). Like Robinson, she did not support the 1985 Anglo-Irish agreement because 'the people who were obliged to work it had not bought into it. And they hadn't been asked to buy into it' (McGarry, 2008: 101-2). In 1984, having previously turned down approaches from Fine Gael, she joined Fianna Fáil. In the early years of her party membership, McAleese shared views on a range of issues with her party leader, Charles $\mathrm{J}$. Haughey. Indeed, her imposition as a candidate for the party in the liberal Dublin South East constituency for the 1987 general election, after failing to win a place on the ticket at the selection convention, was due to Haughey. Her initial foray into electoral politics was unsuccessful (McCarthy, 1999: 79, 81-85). As Haughey began to shift towards acceptance of the Anglo-Irish Agreement, and support for the extradition of Irish republican terrorist suspects to Britain, her disillusionment with him and Fianna Fáil grew. Soon after the 1987 election, the McAleese family returned to Northern Ireland and a new chapter in the public life of Mary McAleese (McCarthy, 1999: 90-94).

McAleese successfully applied for the position of Director of the Institute of Professional Legal Studies at her alma mater, Queen's University Belfast. She beat rival candidate, Queen's law lecturer and member of the Ulster Unionist Party, David Trimble, for the position. The surprise choice of outsider McAleese (a Catholic woman, and nationalist, who had carved political, journalistic and academic careers in the Republic) led to unionist allegations of political interference by Haughey in her selection (McCarthy, 1999: 102-105). Trimble supporters called for a debate in the House of Commons - and the bitterness over the matter lingered for over a decade. In the years following her Queen's appointment, McAleese advanced her career, held a number of directorships, and in 1994 was appointed pro-vice chancellor of the University - the first woman and second Catholic to hold the post. She made a rare high-profile foray into public debate in 1992 on the three-part abortion referendum proposed by the Fianna Fáil-Labour government led by Albert Reynolds. Away from the glare of publicity, she maintained close professional and personal ties to the Catholic hierarchy, and in 1996 became active in the efforts of the Clonard monastery's peace initiative in West Belfast to re-establish the IRA ceasefire. Yet, she remained a strong critic of the doctrinaire, traditional, Catholic hierarchy, especially for its dismissive attitude towards women's role in the Church. ${ }^{7}$ McAleese's career trajectory in academia had reached a plateau by then, but the Irish presidency was not on her mind when Robinson announced her early departure from office on 12 March, 1997.8 


\section{Emergence as President}

Robinson's resignation announcement some months before her term came to a close was unexpected. With her continued high popularity it was generally believed that she would seek a second term. Preparations for candidate selection in all parties were stalled while SDLP leader and peace process architect John Hume considered putting his name forward. Hume delayed clarifying his intentions until 9 September, when he backed away from seeking the office. In the meantime, having been persuaded by close friend Harry Casey ${ }^{9}$ to seek a nomination for the office, Mary McAleese began an informal canvas of the Fianna Fáil membership, building support among influential grassroots networks within the party. This low-key campaign continued through the general election campaign and into the summer. While her candidacy was first suggested in early April by Fr. Alec Reid of Clonard Monastery to Martin Mansergh, Fianna Fáil's special advisor on Northern Ireland, the response to it was muted. ${ }^{10}$ With Fianna Fáil returned to office in June 1997, McAleese decided to test interest in her nomination for the presidency with her old friend and Fianna Fáil deputy leader, Mary O'Rourke. The seasoned politician was supportive of McAleese's ambitions, and conveyed this to her party leader, Bertie Ahern.

The summer of 1997 was defined by overt and covert campaigning for the Fianna Fáil nomination. Former Taoiseach Albert Reynolds had already publicly declared his interest and had put his considerable financial resources into becoming the party's flagbearer. In midAugust former EU Commissioner, Michael O'Kennedy announced his intention to seek the nomination. In the meantime, McAleese party supporters, mobilised by Harry Casey, undertook a concerted letter-writing campaign to their elected representatives advocating her nomination.

With eight days to the Fianna Fáil selection convention, McAleese wrote to Taoiseach Bertie Ahern indicating her interest in being a candidate. At a meeting to informally interview the putative candidate, Ahern revealed little of his personal view on her candidacy, but indirectly encouraged her to continue seeking support from the party's elected representatives. During the following days, Reynolds, O'Kennedy and McAleese intensively canvassed the Fianna Fáil parliamentary party. Addressing the parliamentary party the night before the selection meeting, Ahern indicated that in an ideal world, having a presidential candidate with a track record of service in Fianna Fáil was the ideal outcome. However, he reminded the meeting that an ideal outcome might not be the right one if the party were to have a realistic prospect of regaining the office. He advised his colleagues to vote for the best candidate at the party's selection convention the following day (McCarthy, 1999: 178).

On 17 September 1997, Ahern supporters were openly canvassing for McAleese, convinced that a Reynolds candidacy would be divisive and would fail to return the presidency to the 
party. The first round of voting was inconclusive, with no nominee winning the necessary 57 votes that would constitute an overall majority. On the second round, Kennedy's votes went en bloc to McAleese, giving her 62 votes to 48 for Reynolds, and making her the Fianna Fáil presidential nominee (McCarthy, 1999: 185). The outsider had defeated one of the most senior and experienced Irish politicians. ${ }^{11}$ The outcome was reported as a 'political earthquake'. When asked about her vision for the office, McAleese said that she would use the role of President 'for bringing people to each other simply and solely in friendship'.

The drama of the Fianna Fáil contest was not reflected to the same extent in the other parties. Mary Banotti, member of the European Parliament since 1984 and from a distinguished political family, was proposed as a candidate by the Fine Gael leadership in July, but was not ratified until 16 September when she defeated seasoned politician and former minister Avril Doyle by a narrow margin. Surprisingly, Labour was slow to nominate a candidate, and on 16 September - the day before Fianna Fáil's decisive decision - the party ratified Adi Roche, anti-nuclear campaigner and director of a children's charity. She was backed by Dick Spring, even though party stalwart Michael D. Higgins was available - and in 2011 became Ireland's ninth President (Doyle, 1998: 135-36; Marsh, 1999: 217-221).

The low-key selection of the Fine Gael and Labour candidates stood in contrast to the cliffedge search for a nomination by singer and former Eurovision Song Contest winner, Dana Rosemary Scallon, followed by former garda (police) representative Derek Nally, from the local councils. This was the first time that the constitutionally-provided local government power to nominate a presidential candidate was employed. Although the councils were controlled by the main parties, Scallon mounted a sufficiently convincing case for support based on the argument that she was merely seeking the right to stand for election, and that the voters would be the final arbiters. The main parties did not view her as a major threat to their own candidates, and so assisted in her nomination, as also that of Derek Nally (Doyle, 1998: 136-37).

The election campaign began with Roche in a commanding lead of $38 \%$ in the opinion polls, but early criticisms from co-workers about her abrasive management style dented her support (Marsh, 1999: 224). The campaign quickly became a two-person contest between Banotti and McAleese, with McAleese assuming a commanding position in the polls which was never seriously challenged (Doyle, 1998: 142) A defining moment in the campaign came in mid-October with publication of leaked documents from the Department of Foreign Affairs used to suggest that McAleese was "pushing a Sinn Féin agenda" and should not be trusted'. ${ }^{12}$ This allegation, which had first surfaced during her RTÉ days, was turned into a political weapon by her opponents. Her capacity to be a 'proper' president on this basis was challenged by Derek Nally. He was joined in this theme by Fine Gael leader John Bruton, 
who alleged that McAleese was the 'Sinn Féin endorsed candidate' (Doyle, 1998: 140-41). Eoghan Harris, media commentator and key player in the Robinson presidential victory, went further and in an intemperate news interview described McAleese as a 'tribal time bomb' - an ironic echo of the Padraig Flynn slur on Robinson's character seven years previously (McCarthy, 1999: 200-201; McGarry, 2008: 173-180). The effect was to swing public support in favour of McAleese while damaging the campaigns of the other candidates. McAleese also countered these attacks, speaking for the first time in public about her involvement in the peace initiative in west Belfast. The attacks also provoked the Belfast-based Irish News to robustly defend McAleese and castigate Bruton for his insensitive remarks (McGarry, 2008: 179). Even the Unionist politician John Taylor, who had bitterly opposed her appointment at Queen's some years earlier, came out in support of McAleese, declaring her 'by no means a Republican sympathiser' (McCarthy, 1999: 196-214).

This political storm worked to the benefit of McAleese in a number of ways. It cemented the allegiance of Fianna Fáil and mobilised party members into campaigning for her. It brought her to public attention, turning a relatively unknown candidate into a household name. Finally, it enabled her to campaign in a more confident and self-assured manner. She turned the allegations into a positive peace-building theme, in keeping with her campaign slogan 'Building Bridges'. Banotti's support fell further after Bruton's attack, and the media attention on McAleese deprived Banotti of an essential platform to press home her claim to the office. The controversial allegations resulted in the collapse of Nally's campaign, and Dana's support remained marginal throughout, despite her competent and professional media performances.

The result reflected the poll patterns from mid-October onwards: McAleese secured over $45 \%$ of first preferences, with Banotti securing over $29 \%$ and the other candidates trailing some distance behind. With the support of transferred votes, McAleese won convincingly on the second count, with $59 \%$-- the first northern nationalist to hold presidential office in the Republic (Doyle,1998: 143). On Tuesday 11 November 1997, Mary McAleese succeeded Mary Robinson as President of Ireland. Seven years later, she was again inaugurated as President, having been returned unopposed for a second term.

\section{Vision of office}

As a noted American political communication expert has observed, 'democracy is based on empathy, that is, on citizens caring about each other and acting on that care, taking responsibility not just for themselves but for their families, communities, and their nation' (Lakoff, 2011). This empathic understanding of democracy was evident in the McAleese presidency, from her inaugural address through to the end of her 14 years in office. In contrast to the directness of Robinson, her first inaugural speech was dominated by poetic 
imagery of caring, offering to "point the way to a reconciliation of these many tensions and to see Ireland grow ever more comfortable and at ease with the flowering diversity that is all around us' (McAleese, 1997). By the time of her second inaugural speech, McAleese, still with a poetic turn of phrase, had consolidated this empathic, facilitatory style with more precision while retaining the caring aspect, as she sought to 'nurture and celebrate commitment to community and to responsible citizenship and to encourage self-belief among the most marginalized' (McAleese, 2004).

In her first inaugural address, McAleese voiced a preoccupation with the peace process in Northern Ireland, an issue with which she was closely associated and a defining issue during the electoral contest. In announcing the theme of her presidency as 'Building Bridges', McAleese sought to reassure her critics that she would facilitate consensus-building and peace-making as 'work I want to help in every way I can.'

McAleese also conveyed her own religious faith unambiguously in this inaugural speech - a counterpoint to Robinson's humanistic beliefs. In doing so, she was affirming a sense of national bonding through shared Christian values. This was a difficult issue to raise in a political setting, yet for her presidency to be widely accepted, McAleese had to give a signal that she would be a non-sectarian head of state. Thus, her references to religion were carefully crafted to appeal to the faithful of all beliefs. When publicly berated by then Archbishop of Boston, Cardinal Bernard Law in 1998 for supporting the ordination of women and being a 'poor Catholic president', McAleese replied: 'I am not a Catholic president. I'm president of Ireland...I happen to be Catholic' (McGarry 2012). Indeed, as an event early in her presidency would show, McAleese was not afraid to challenge Catholic orthodoxy in a clash of religion, ethics and politics. On the invitation of the Church of Ireland (Anglican) Archbishop of Dublin, she took communion in an inter-faith service and was strongly criticised for so doing by the Catholic Archbishop of Dublin. Her actions were rewarded with $78 \%$ popular support. ${ }^{13}$

By the time of her second inaugural address in 2004, the peace process was well established. As she accomplished her first term agenda, and gained experience of being a head of state, McAleese became more comfortable in situating Ireland in a wider context. She saw that the country could make a distinctive contribution to make to global development, as

Ireland's fortunes are linked to global politics as never before and though we are a small peripheral island we have a fascinating and exceptional engagement with the world that spans every conceivable connection ... As President I have a key role in the renewal and development of ties to our global Irish family (McAleese, 2004). 
This was a similar perspective to that of Robinson, who was acutely aware of promoting Ireland's role in a global context. McAleese more frequently acknowledged a new, modern and diverse Ireland - echoing another strong theme in Robinson's presidency. She also drew attention to the challenges to social well-being brought by Ireland's newly acquired prosperity. Tackling these new problems, embedding the peace process, and contributing to global challenges were identified as priorities for her second term. While individually significant issues, they were fragmented, lacking the unifying power of the 'building bridges' theme that had lent normative coherence to her activities in the first term and informed her reconciliatory agenda in the second term.

The similarity in value emphasis, coming from women of very different ideological dispositions, seems to indicate that as McAleese became familiar with being a symbol of the nation - a role that the politically-experienced Robinson had appreciated - she placed greater emphasis on modern Ireland's contribution at home and abroad to universalist social values of solidarity and inclusion. However, it is open to interpretation as to whether McAleese gave effect to these universalist values in a global context as she worked through her second term.

\section{Political role}

In the initial weeks of her first-term as President, Mary McAleese travelled to Northern Ireland on the first of many official visits. On arrival at Belfast City Airport, she was greeted in Irish by the Deputy Lord Lieutenant for Belfast, Col. Charles Hogg. Later that day, Danny Kennedy of the Ulster Unionist Party welcomed her to Newry, and in west Belfast she met and shook hands with Sinn Féin leader Gerry Adams (McGarry, 2008: 196-197). This unity in welcome, presaged by Taylor's endorsement of her candidacy during the campaign, suggests that the northern interest in building a new relationship with the south was shared across the communities. By the end of her 14-year period as President, McAleese had officially visited Northern Ireland on over one hundred occasions, only one of which was the subject of protest.

The theme of reconciliation emerged as the dominant motif of her first term of office. It was characterised by a Twelfth of July garden party at the Áras where representatives from both communities in Northern Ireland mingled with invited groups and politicians. Her husband, Martin McAleese, worked behind the scenes with former loyalist paramilitary leaders and communities to bring these marginalised representatives into the peace process. Indeed, the President symbolically used the office to emphasise the shared aspects of history between Britain and Ireland. The joint inauguration in 2006 of the Island of Ireland Peace Park at Messines, Belgium by President McAleese, Queen Elizabeth II and King Albert II of Belgium, in memory of all soldiers from Ireland who served in World War I, was a powerful moment of 
reconciliation. The last taboo in Anglo-Irish relations was broken towards the end of her presidency, with the visit of the UK monarch to Ireland in 2011. The personal warmth between the two women, and the responsive welcome of Irish people, was a fitting celebratory capstone to the normalisation of Anglo-Irish relations fostered by Robinson and continued by McAleese.

Mary McAleese's complex relationship with the Catholic Church continued, especially during her first term: on the one hand, she continued to profess a strong personal religious faith and commitment to Catholic orthodox teaching, while on the other, she was critical of Church structures and exclusionary practices. Her regular attendance at ecumenical services, and her welcoming of liberal Church-related groups such as BASIC (Brothers and Sisters in Christ $)^{14}$ to Áras an Uachtaráin illustrates her commitment as head of state to recognising religious plurality.

The other major dimension of her two terms in office was her representation of Ireland abroad as a place of business and trade, a feature of earlier presidential terms. This aspect of McAleese's activity, however, became more prominent in her second term. Many of her state visits were undertaken with a view to the economic advantage to Ireland, with her visit to China in June 2010 of particular interest. Concerns about human rights in that emerging economic superpower were soft-pedalled during her visit in favour of the commercial benefits to Ireland, a contrasting emphasis to that represented by Robinson. Yet, woven within those economic promotional trips were instances of recognition of the Irish diaspora and the work of Irish missionaries. The tackling of global challenges promised in the second inaugural speech did not materialise to any extent.

In her second term, with the political drama of the Irish peace process settling into routine political activity, McAleese placed a greater emphasis on the social problems of the day increases in suicide, drug misuse, poverty and social alienation. Many of the visitors received by McAleese in the Áras, and visited by her in their communities, were from organisations working to alleviate social problems and integrate marginalised groups, such as representatives of the Traveller community, disability action groups, special Olympics interests, and suicide and drug prevention activists, among others. Like Robinson, her vision of a democratic polity was an inclusive one, and in this term, too, she continued her predecessor's practice of valuing the public commitment displayed by groups and individuals in marginalised communities.

Yet, writing a mid-term assessment of the McAleese presidency, journalist Justine McCarthy (2007: 2) expressed the critical view that the incumbent had lost her way in the second term: 
the peace process is as good as complete, rendering redundant her mission to build bridges....within the narrow confines of cross-border bonding, as she has defined it ... in the afterglow of lan Paisley's benign power grab and his avuncular handshake with Bertie Ahern at Farmleigh, the North has receded as a significant national issue.

There is some truth in this assertion. McAleese had finally conformed to the political status quo, losing her essential radicalism once the peace process became embedded in regular democratic politics. She continued to carry out the duties of her office with commitment and care, but without the guidance of a new narrative or an all-encompassing slogan. The promise of meaningful engagement on a global stage was not substantively realised. It could be argued that in assuming a second term of office without going through the scrutiny of an election process, McAleese unwittingly lost an opportunity to carve out a fresh political agenda, settling instead for the relative comfort of modest and by now familiar public expectations. She continued to speak out on the social ills of society while continuing to be the 'primary ambassador' for Ireland on trade delegations abroad. ${ }^{15}$ As the fiscal and economic crisis became apparent from 2007 onwards in Ireland, McAleese drew more attention to initiatives with economic and employment potential. In addition, the historic state visit of Queen Elizabeth II to Ireland in May 2011 marked an important moment of reconciliation between the two states. However, without a new value-based theme, in addition to that of reconciliation, upon which to structure the representative power of the office, the symbolic leadership that had characterised her first term diminished.

\section{Transforming the office of President}

Robinson and McAleese brought a fresh energy to what had become a staid office. They sought to refashion the Irish presidency in line with the themes and issues they identified in the course of their election campaigns. The vision offered for the office by each woman is encapsulated in her inaugural address. From this formal speech penned by the incoming president and untainted by the influence of party political priorities, one can glean much about the agenda to follow. In both instances, it was a vehicle for expressing the nature of the relationship that the new President wished to foster with the public, be it one of bonding (that is, using the commonality of 'Irishness' to connect people of differing backgrounds) or bridging (that is, reconciling people of different cultural, political persuasions). Given, too, that the island of Ireland was a chronically divided polity during each president's terms of office, the inaugural address affords an insight into the presidential approach to this concern. The addresses also convey the intention of the new president in defining the place of Ireland on a world stage. Each woman took the opportunity of her inaugural address to articulate her position on these matters, using her new authority as head of state to map her future role and her relationship with the people of Ireland. 
At the time of her election, Robinson was not representative of mainstream public opinion. Aware of this fact, she chose to emphasise the similarities among Irish people, and in doing so sought to bridge the divide between her, as President, and the people. She therefore had to reassure the public that she acknowledged differences in their respective views, while suggesting that these differences were positive, and part of a modern society.

Mc Aleese had fewer 'firsts' to contend with. Ideologically and culturally, she conformed to the dominant values of Irish politics and society to a greater extent than Robinson. She was the second female President, so her gender no longer held as much 'novelty value'. She was a devout Catholic, which reassured conservative groups that had been uneasy with Robinson's humanist orientation. In addition, she was the candidate of the dominant party of the time, Fianna Fáil. McAleese, then, did not present the same perceived potential for destabilising the office as had Robinson. Yet, she was also different: the first President to come from Northern Ireland. McAleese's 1997 inaugural address shows awareness of the need for her to identify with the nation, while promoting peace on the island. In her second inaugural address in 2004, McAleese has already defined her presidential relationship with the people, and spent less time on this point. Nonetheless, she repeated the importance of bridging the divide in understanding between the communities on the island and in building a 'shared future'.

The more muted concern with trust-building among and between communities in the second McAleese address is replaced by a stronger focus on Ireland's relations with the wider world - reflecting her experience in representing the state abroad over the previous seven years. In contrast, Robinson sought to firmly place Ireland in a wider context on a number of occasions in her inaugural speech: as part of a 'new integrated Europe', and with a role as 'a moral and political conscience in world affairs'. Robinson developed this theme in a more substantial manner than her successor, locating Ireland's role in the wider world in terms of 'respect for human rights, pluralism, tolerance and openness to new ideas'. She held out the prospect of a relevant role for the country in a wider context, with 'something "strange and precious" to contribute to the sea-change presently sweeping through the entire continent of Europe'.

Robinson's relationship as head of state to Northern Ireland was equally explicit. She sought to 'encourage mutual understanding and tolerance between all the different communities sharing this island'. McAleese too, sought to foster peace-making efforts, to 'do my best to make us comfortable in each other's company and unafraid of a shared future.' The direct manner in which both women addressed the Northern issue was a departure from past presidential practice. While context may have shaped their thoughts and words, addressing the conflict and its legacy for relationships on the island was a sign that they were going to use their presidential term in pursuit of a political objective. Although ostensibly 'above 
politics', both Robinson and McAleese declared an intention to find a way to act presidentially in a political context.

As each woman worked through her presidency, she gave content to these inaugural address themes in innovative ways, while staying within the constitutional boundaries of the office. Thus, both women contributed to transforming the office through utilising the soft, persuasive and symbolic powers vested in the presidency.

\section{Conclusion}

Irish presidents have a distinctive role as cultural signifiers of the nation - a role that the first President of Ireland (1938-45), Douglas Hyde, fulfilled. Hyde was a figure of reconciliation in a society seeking to establish its newly-won independent status while bearing the recent memory of internal conflict (see chapter 5 ). This role was revived by Robinson and McAleese in different ways. Both women were highly conscious of the symbolic content, and potential, of the presidential office. In their inaugural speeches, they conveyed how they intended to use this symbolic power. As activists by inclination, both women understood the importance of valuing and fostering social engagement. Instinctively, they gravitated towards local, community and grassroots endeavours, appreciating that recognition by the President endowed these efforts with authority and validity in the wider society, and, indirectly, in politics. That validation would be used in different ways, with different purposes, by Ireland's two female presidents. Robinson would use her presidency to create a sense of shared identity and communal endeavour; McAleese would emphasise the importance of reconciling different identities in a shared understanding, and mutual respect, of different traditions.

Robinson's presidential role fitted that of a classical 'representative', employing to effect the aspects of delegate and trusteeship that this concept implies. McAleese fashioned her role around the concept of 'facilitator' - a looser definition than that employed by her predecessor. It served her well during her first term when the sensitive process of peacebuilding dominated politics, but underminded her capacity to exploit the soft power of the presidency later in her second term. However, McAleese had a personal quality of empathy, seen at its best in unscripted and compassionate responses to the 1998 Omagh bombing and the attack on the World Trade Centre in New York in September 2001 (O'Dowd, 2011). Both presidents defined, and were defined by, the manner in which they interpreted the office and the personality they brought to this task. They left a combined legacy of an activist presidential role, endowed with heightened public visibility and renewed sense of relevance for the people and for the politics of the time. It is a measure of their success that towards the end of their terms of office, each woman was more popular with the public than they were on their presidential election day. 


\section{References}

Bresnihan, V. (1999) The symbolic power of Ireland's President Robinson, Presidential Studies Quarterly, 29 (2), pp. 250-262.

Doyle, J. (1998) The Irish Presidential Election 1997, Irish Political Studies ,13, pp.135-44.

Finlay, F. (1990) Mary Robinson: A President with a Purpose (Dublin :The O'Brien Press).

Horgan, J. (1997) Mary Robinson: An Independent Voice (Dublin: The O’Brien Press).

Lakoff, G. (2011) Obama returns to his moral vision: Democrats read carefully!, available at http://www.huffingtonpost.com/george-lakoff/obama-returns-to-hismora_b_850295.html?ref=email_share (accessed 12 March 2012).

Mac Mánais, R. (2005) The Road from Ardoyne: The Making of a President (Dingle: Brandon Press).

Marsh, M. (1999) The making of the eighth President, in M. Marsh and P. Mitchell (eds) How Ireland Voted 1997, pp. 215-42 (Boulder, CO: Westview Press and PSAI Press).

McAleese, M. (1997) Inaugural address. Available http://gos.sbc.edu/m/mcaleese.html (accessed 16 August 2012)

McAleese, M. (2004) Inaugural address. Available http://www.emigrant.ie/index.php?option=com_content\&task=view\&id=37058\&ltemid=18 (accessed 16 August 2012)

McCarthy, J. (1999) Mary McAleese The Outsider: An Unauthorised Biography (Dublin: Blackwater Press).

McCarthy, J. (2007) Mary McAleese - Strutting without purpose available at http://politico.ie/politics/4626-mary-mcaleese-strutting-without-purpose.html (accessed 9 March 2012).

McGarry, P. (2008) First Citizen: Mary McAleese and the Irish Presidency (Dublin: The O'Brien Press).

McGarry, P. (2012) McAleese in support of same-sex marriage available at http://www.irishtimes.com/newspaper/ireland/2012/1009/1224325059039_pf.html (accessed 12 January 2013)

O'Dowd, N. (2011) Why Irish America owes much to departing president Mary McAleese, available at http://www.irishcentral.com/news/Why-Irish-America-owes-much-to-departing-president-MaryMcAleese-133521693.html?showAll=y (accessed 22 March 2012).

O'Leary, O., and Burke, H. (1998) Mary Robinson: The Authorised Biography (London: Hodder and Stoughton).

O'Sullivan, E. (1991) The 1990 presidential election in the Republic of Ireland, Irish Political Studies, 6, pp. 85-98.

Robinson, M. (1997) Inaugural address. Available http://prelectur.stanford.edu/lecturers/robinson/inaugural.html (last accessed 16 August 2012) 
Siggins, L. (1997) Mary Robinson: The Woman Who Took Power in the Park (Edinburgh: Mainstream Publishing).

\section{Notes}

1. At the time, Catholic students wishing to study in Trinity College, Dublin required special permission from their local bishop. Mary Bourke's two older brothers were already at Trinity studying medicine, having been granted permission in this way. When her parents sought the same permission for their daughter, the necessary letter of recommendation from Bourke's school principal to the local bishop was not forthcoming. Her parents instead sought and received permission from the Archbishop of Dublin, John Charles McQuaid (Siggins 1997: $37-$ 8). The ban on Catholics attending Trinity College was lifted in 1970.

2. For unionist reaction, see also http://cain.ulst.ac.uk/events/aia/reaction.htm.

3. The SDLP was founded in 1970 by Currie, John Hume and others as a constitutional nationalist party in Northern Ireland (NI). It sought a peaceful solution to the economic, social and political discriminations suffered by nationalists under unionist-dominated rule. Currie held an SDLP seat in the Northern Ireland Assembly from 1973-74, and briefly held a ministerial position in the power-sharing executive until its collapse in May 1974. He relocated to Dublin in 1989 and in the same year was elected to the Dail for Fine Gael (O'Sullivan 1991: 89-90).

4. Stephen E. Lucas, quoted in CBS News, 'The Power of Oratory', 11 February 2009. Available at http://www.cbsnews.com/2100-3445 162-3732704.html (accessed 6 September 2012).

5. John McManus, her maternal grandfather, joined the IRA in 1921 and fought in the War of Independence. He returned to his home town of Dromara, Co. Down after the 1921 Anglo-Irish Treaty brought hostilities to an end (Mac Mánais, 2005: 20-21).

6. The Reid professorship is an early-career position, combining lecturing and academic activity with practice at the Irish bar.

7. Interview with Mary McAleese: Vincent Browne, Sunday 01 February 1998. Available at http;//politicio.ie/component/content/article/221-politics/5004-interview-with-mary-mcaleese.htm (accessed 15 Mar 2012).

8. http://news.bbc.co.uk/2/hi/europe/1680695.stm (accessed 2 Dec 2011)

9. Harry Casey taught religion and English at second level in Navan, Co. Meath. He shared the deep religious faith of the McAleese couple, and became their close friend and confidante. $\mathrm{He}$ was her director of elections in 1987 (Mac Mánais, 2005: 302-303).

10. Mansergh, who had a distinguished career in the Irish Department of Foreign Affairs, became special advisor on Northern Ireland to successive Fianna Fail leaders. He was closely connected with the Irish peace process. 
11. RTE news report on McAleese nomination:

http://wn.com/Mary_McAleese_beats_Albert_Reynolds_for_Fianna_Fail_Presidential_Nominati on,_September_1997 (accessed 29 July 2011)

12. The Sunday Times, 19 October 1997 'SDLP linked McAleese to Sinn Féin', quoted in http://sluggerotoole.com/2011/09/27/from-aras97-to-aras11-has-the-media-decommissioned/, (accessed 16 August 2012)

13. The Independent, 23 December 1997 'Faith: Catholics angered by Irish president taking Protestant communion', available at http://www.independent.co.uk/news/faith-catholicsangered-by-irish-president-taking-protestant-communion-1290292.html (accessed 16 August 2011).

14. McAleese received members of BASIC to the Áras on 9 November 1998.

15. Self-description of her representative functions as head of state accompanying delegations to market Ireland in other parts of the world; Paul Clarkson, 'I want another seven years: President Mary's poll dream', The Mirror, 15 October 2003, available at http://www.thefreelibrary.com/l+want+another+SEVEN+years\%3B+PRESIDENT+MARY'S+PO

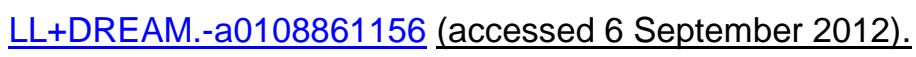

